\title{
エビングハウス錯視に左右の配置が及ぼす影響について
}

\author{
○実吉綾子 \\ (帝京大学文学部) \\ キーワード : エビングハウスの錯視、
}

The effect of left

right alignment of figures on the Ebbinghaus illusion.

\section{Ayako SANEYOSHI}

(Teikyo University)

Key Words: Ebbinghaus illusion,

\section{目 的}

同じ大きさの円が周囲を異なる大きさの円で囲まれている 時、周囲の円が大きい場合には中央の円が小さく、周囲の円 が小さい場合には中央の円が大きく知覚されるというエビン グハウスの大きさの錯視は、多くの教科書や知覚に関するウ エブページで紹介されている。説明に添えられた錯視の図は、 多くの場合二種類のエビング八ウス錯視を横に並べたもので ある。この時、周囲が小さい円で囲まれた刺激を右に、大き い円で囲まれた刺激を左に配置する傾向が認められた。例え ばインターネットでエビングハウスの錯視を紹介しているぺ ージを検索したところ、44 件中 27 件で右に小さい円で囲ま れた刺激を配置していた。このような傾向はなぜ生じるのだ ろうか。本研究では錯視がより効果的に生じる配置を選択し ている可能性に注目し、エビングハウスの錯視の錯視量が左 右の配置によって変わるのかどうかを確認する。

\section{方 法}

実験参加者 大学生ならびにスタッフ 12 名 (19 歳から 35 歳) 実験デザイン 周囲の円の大きさ(小/大／なし: 小大それぞ れ直径視角 $\left.0.42^{\circ} / 2.92^{\circ}\right) \times$ 中央の円の大きさ (小 $/$ 中 $/$ 大：それぞれ直径 $\left.\left.1.25^{\circ} / 1.67^{\circ} / 2.08^{\circ}\right)\right) \times$ 錯視図形の 配置位置 (右／左）: なお周囲の円がない場合は参照にする円) の 3 要因の参加者内計画であった。

刺激 灰色の背景に白でエビングハウス錯視と調整円を描画 した。中央の円と周囲の円の距離は周囲の円の大きさごとに 常に一定であった（周囲の円が小さい場合は 10 ピクセル、周 囲の円が大きい場合は 57 ピクセル)。調整用の円は半径 5 ピ クセルと 35 ピクセルの 2 種類が作成された。

課題と手続き 暗室にて実験を行った。実験参加者はあご台 にあごをのせ、教示の後、周囲の円がない条件で練習を 4 試 行おこない、続けて本実験を行った。1 試行では、まずビー プ音とともに注視点が 500 ミリ秒提示され、続いて刺激が提 示された。左右どちらかに調整用の円、もう一方に刺激が提 示された (図 1 参照)。参加者は指定されたキーを左右の人差 し指で押し、調整円の大きさを錯視図形の中央の円、もしく はもう一つの円と同じ大きさに調整するよう教示された。ま た、調整中は左右に視線を向けてよいが、最後の確認は注視 点をみながら行うように教示された。1 8 試行を 1 ブロックと し、4ブロック計 72 試行であった。ブロック内では各条件が ランダムに提示された。

\section{結果と考察}

周囲の円の大きさ $\times$ 中央の円の大きさ $\times$ 配置位置の反復測 定の分散分析を行った。その結果、周囲の円の大きさの主効 果が認められ $(F(2,22)=105.0, p<.001)$ 、周囲の円が小さい条 件では中央の円が大きく、周囲の円が大きい条件では中央の 円が小さく知覚された。したがって、エビングハウスの錯視
が生じていることが確認された。また、周囲の円の大きさメ 中央の円の大きさ $\times$ 視野の交互作用が有意傾向にあったため $(F(4,44)=2.50, p=.056)$ 、中央の円の大きさごとに周囲の円 の大きさ $\times$ 配置の分析を行ったところ、中央の円の大きさが 大きい条件で、周囲の円の大きさが小さい時に右に錯視が配 置された時の方が左に配置された時よりも錯視量が有意に大 きかった $(p=.016)$ 。

本研究の結果、周囲の円が小さい条件では、図形が右に配 置された方が左に配置された場合よりも錯視量が増え、より 中央の円が大きく知覚されることが示唆された。したがって、 周囲の円が小さい図形を右に配置するのは、錯視がより効果 的に生じる選択を行っているためと考えられる。ではなぜ右 に配置した方が錯視量が多くなるのだろうか。空間的注意の 操作は左視野を支配する右半球に処理優位性があることが示 唆されている（Mangun et a1., 1994）。また、エビングハウス の錯視は周囲の円を無視して中央の円に注意を向けることに よって錯視量が減ることが報告されている（(Shulman，1992）。 したがって、錯視図形が左に提示された場合は、周囲の円の 処理を抑制し中央の円の大きさに注意を向けられることでよ り正確に中央の円が知覚され、相対的に右に提示された条件 では錯視量が増えたのではないだろうか。今後、注意の配分 を操作し、配置の効果がどのように変化するかを検討する。

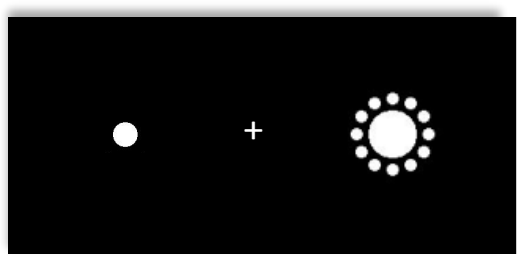

図 1. 刺激例 : 右が錯視図形、左が調整円

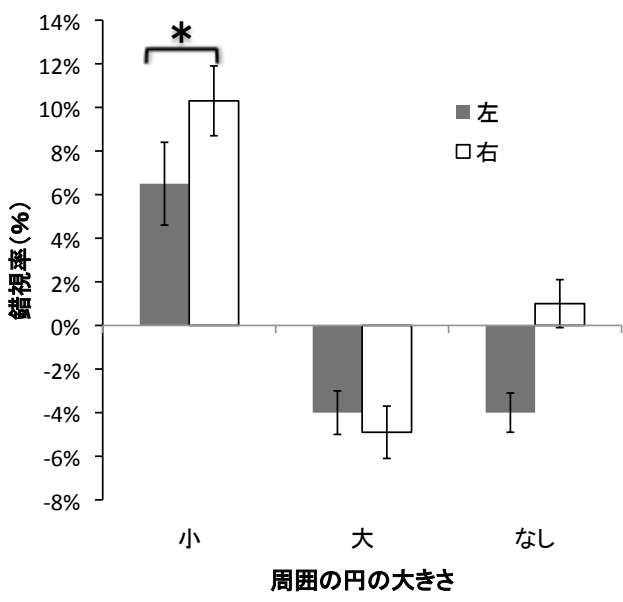

図 2. 中央の円が大きい条件の周囲の円の大きさ $\times$ 配置の結果 